\title{
PROGRAM PENYUSUTAN ARSIP DINAMIS DI REKTORAT UNIVERSITAS NEGERI YOGYAKARTA
}

\author{
Adhitya Eka Putri \\ Sub-Bagian TU dan Kearsipan UNY \\ (adhityaeka@uny.ac.id)
}

INTISARI

\begin{abstract}
Dalam penyelenggaraan kegiatan administrasi, setiap lembaga perguruan tinggi selalu menghasilkan catatan/rekod. Tidak sedikit rekod, yang juga disebut sebagai arsip dinamis, tercipta melalui kegiatan persuratan. Perguruan tinggi membuat dan menerima surat dalam rangka melaksanakan kegiatan universitas. Seiring dengan waktu, arsip dinamis yang tercipta melalui kegiatan persuratan akan terus bertambah sehingga diperlukan ruangan, sarana dan prasarana, serta biaya yang semakin besar. Dalam rangka merespon persoalan tersebut, perlu dilakukan program penyusutan arsip dinamis agar volume arsip dinamis dapat dikendalikan secara terprogram. Penelitian ini dilakukan terhadap kegiatan penyusutan arsip dinamis di Universitas Negeri Yogyakarta pada tahun 2015-2017. Penelitian ini dilakukan dengan metode kaulitatif dengan pendekatan studi kasus. Penelitian ini bertujuan untuk menjabarkan program penyusutan arsip dinamis serta hambatan-hambatan yang dihadapi dalam kegiatan tersebut. Hasil penelitian menunjukkan bahwa kegiatan pemindahan arsip inaktif dapat dilakukan, namun untuk kegiatan pemusnahan dan penyerahan belum dapat terlaksana karena berbagai sebab.
\end{abstract}

Kata Kunci: persuratan, penyusutan arsip dinamis, Universitas Negeri Yogyakarta

\begin{abstract}
In administering administrative activities, every tertiary institution always produces records. Not a few records are created through correspondence activities. Universities make and receive letters in order to carry out university activities. Over time, the records created through correspondence activities will continue to grow so that space, facilities and infrastructure are needed, and costs are even greater. In order to respond to these problems, a records disposal program is needed so that the volume of the records can be programmed. This research was conducted on records disposal activities at Universitas Negeri Yogyakarta in 2015-2017. This research was conducted using the caulifative method with a case study approach. This study aims to describe records disposal programs and the obstacles faced in these activities. The results of the study indicate that the records transfer activities can be carried out, but for the destruction and submitting activities it cannot be carried out due to various reasons.
\end{abstract}

Keywords: correspondence, records disposal, Universitas Negeri Yogyakarta 


\section{PENGANTAR}

\section{Latar Belakang Masalah}

Surat menyurat menjadi bagian tak terpisahkan dalam penyelenggaraan kegiatan administrasi organisasi. Surat-surat dalam kegiatan kedinasan lebih dikenal sebagai surat dinas. Dalam Peraturan Menteri Riset, Teknologi, dan Pendidikan Tinggi Republik Indonesia nomor 51 tahun 2015 tentang Tata Naskah Dinas di Lingkungan Kementerian Riset, Teknologi, dan Pendidikan Tinggi disebutkan bahwa surat dinas, yang merupakan bagian dari naskah dinas, merupakan naskah dinas yang berisi hal penting berkenaan dengan administrasi pemerintahan. Dalam peraturan tersebut juga disebutkan bahwa naskah dinas adalah informasi tertulis sebagai alat komunikasi kedinasan yang dibuat dan/atau dikeluarkan oleh pejabat yang berwenang. Selain surat dinas, yang termasuk naskah dinas adalah peraturan; keputusan; instruksi; prosedur operasional standar; surat edaran; surat tugas; nota dinas; memo; surat undangan; nota kesepahaman; surat perjanjian; surat kuasa; surat pelimpahan wewenang; surat keterangan; berita acara; surat pengantar; surat pernyataan; pengumuman; laporan; telaahan staf; dan notula rapat.

Surat dinas digunakan sebagai media komunikasi yang efektif dan cukup relevan pada saat ini. Surat mampu mengatasi keterbatasan ruang dalam komunikasi. Setiap hari, Universitas Negeri Yogyakarta (UNY) membuat dan menerima surat dinas, baik dari instansi pemerintah, instansi swasta, maupun perseorangan. Oleh karena luasnya lingkup pekerjaan dan tingginya aktivitas organisasi, terjadi akumulasi penciptaan surat dinas di UNY.
Sebagian surat dinas yang tercipta memiliki nilai guna berkelanjutan, seperti nilai guna kesejarahan, keuangan, administratif, dan nilai kebuktian. Namun tidak sedikit pula surat dinas yang tercipta tidak memiliki nilai guna setelah selang beberapa waktu yang berbeda.

Akumulasi ini menyebabkan berbagai persoalan baru dalam hal penyimpanan surat. Selain dibutuhkannya ruang yang memadai, dibutuhkan pula biaya yang tidak sedikit untuk mempersiapkan sarana dan prasarana penyimpanan arsip dinamis. Paknad dan Luellig (2011:60) menyatakan bahwa penyimpanan data tidaklah murah. Mereka menambahkan bahwa beberapa orang mungkin berpendapat bahwa menyimpan data pada kenyataannya menggunakan pendekatan yang valid selama data diindeks dengan benar dan oleh karena itu data dapat dicari. Tetapi sayangnya pencarian dan pengindeksan data tidak akan menunjukkan koleksi yang dimiliki, seberapa nilai gunanya, dan apa yang harus dilakukan kemudian.

Selain mebutuhkan biaya yang besar, kondisi ruang yang semakin sempit memberikan beban psikologis tersendiri bagi petugas penyimpanan arsip dinamis. Ruangan menjadi terasa sempit dan tidak nyaman, sehingga bukan tidak mungkin hal ini berpengaruh pada kinerja karyawan.

Dalam rangka merespon persoalan tersebut, UNY bermaksud melakukan kegiatan penyusutan arsip dinamis, baik berupa kegiatan pemindahan arsip inaktif, pemusnahan arsip yang tidak memiliki nilai guna, maupun penyerahan arsip statis ke lembaga kearsipan. 


\section{Rumusan Masalah}

Penelitian ini menyajikan permasalahan pelaksanaan kegiatan penyusutan arsip dinamis di UNY sejak tahun 2015-2017. Sub-Bagian Tata Usaha dan Kearsipan UNY sebagai pelaksana kegiatan kearsipan di Rektorat UNY tentu mengalami permasalahan berupa hambatan, dan sekaligus memiliki tantangan dalam penyelenggaraan kearsipan, khususnya penyusutan arsip dinamis.

Melalui permasalahan tersebut, penulis menyusun pertanyaan penelitian secara umum sebagai berikut: bagaimanakah pelaksanaan penyusutan arsip dinamis di Rektorat Universitas Negeri Yogyakarta, kendala apa saja yang dihadapi, dan alternatif apa yang ditawarkan agar program ini dapat dilaksanakan? Dari pertanyaan umum tersebut, munculah pertanyaan yang lebih spesifik, yaitu:

1. Bagaimanakah pelaksanaan pemindahan arsip inaktif di Rektorat UNY?

2. Bagaimanakah pelaksanaan pemusnahan arsip yang tidak memiliki nilia guna di Rektorat UNY?

3. Bagaimanakah pelaksanaan penyerahan arsip statis di Rektorat UNY?

4. Kendala apa saja yang dihadapi dan solusi apakah yang ditawarkan untuk menyelesaikan persoalan tersebut?

\section{Tujuan Penelitian}

Tujuan penelitian ini adalah untuk meningkatkan pemahaman tentang perlunya kegiatan penyusutan arsip dinamis, serta mengetahui penyelenggaraan kegiatan penyusutan arsip dinamis di UNY. Tulisan ini diharapkan dapat bermanfaat dalam pelaksanaan kegiatan penyusutan arsip dinamis yang lebih komprehensif pada khususnya, dan penyelenggaraan kearsipan universitas pada umumnya.

\section{Metodologi Penelitian}

Penelitian ini dilakukan dengan pendekatan kualitatif, yaitu suatu penelitian dengan memberikan perhatian yang seksama dan terperinci terhadap suatu hal yang berhubungan dengan suatu fenomena itu secara alamiah sesuai dengan kenyataan yang ada (Pendit, 2003:264). Jenis penelitian yang digunakan adalah deskriptif, yaitu suatu metode dalam meneliti status sekelompok manusia, suatu objek, suatu set kondisi, suatu sistem pemikiran, ataupun suatu kelas peristiwa pada masa sekarang (Nazir, 2017:43), dengan pendekatan studi kasus, yaitu penelitian tentang status subjek penelitian yang berkenan dengan suatu fase spesifik atau khas dari keseluruhan personalitas (Maxfield, 1930 dalam Nazir, 2017:65).

Menurut Pendit (2003:251), penelitian studi kasus harus dibatasi pada lingkup tertentu. Batasan pada penelitian ini adalah pelaksanaan kegiatan penyusutan arsip dinamis di UNY sejak tahun 2015-2017. Dalam pengumpulan data, dilakukan teknik wawancara, observasi, dan studi dokumentasi. Sevilla (1993:75) menyatakan bahwa wawancara adalah suatu metode penelitian yang meliputi pengumpulan data melalui interaksi verbal secara langsung antara pewawancara dengan responden. Sementara itu, observasi dilakukan untuk melengkapi data yang diperoleh dari wawancara.

Studi dokumentasi menghasilkan data sekunder. Data sekunder adalah data yang 
diperoleh secara tidak langsung dari sumber datanya. Sarwono (2006:123) mendefinisikan data sekunder sebagai data yang telah tersedia sehingga peneliti tinggal mencari dan mengumpulkan.

Salah satu syarat bagi analisis data adalah dimilikinya data yang valid dan reliabel. Adapun untuk mencapai validitas data dalam penelitian ini dilakukan dengan cara uji kredibilitas yaitu dengan menambah ketekunan, triangulasi, dan member check. Penelitian ini menggunakan teknik analisis data menurut Miles dan Huberman yang dikenal sebagai model interaktif. Miles dan Huberman (1992) dalam Idrus (2009:147) menyatakan bahwa model interaktif terdiri atas tiga hal utama, yaitu: (1) reduksi data, (2) penyajian data, dan (3) penarikan kesimpulan/verifikasi.

\section{Kerangka Pemikiran}

Dalam pelaksanaan tugas administrasi universitas, kegiatan persuratan menjadi hal yang secara otomatis terjadi dan tidak dapat dielakkan. Sebagai sarana komunikasi yang bersifat formal dan mampu mengatasi keterbatasan ruang, kegiatan surat-menyurat menjadi sarana transfer informasi yang efektif dan relevan bagi berbagai pihak.

Tingginya volume surat-menyurat di UNY mengakibatkan meningkatnya koleksi surat sebagai arsip dinamis. Keterbatasan ruang simpan sementara untuk arsip dinamis menuntut tindakan lebih lanjut. Arsip dinamis yang frekuensi penggunaannya telah menurun harus dipindah dari ruang utama kegiatan administrasi (berupa central file) ke ruang penyimpanan sementara (berupa records center). Sementara itu, arsip yang tidak bernilai guna perlu untuk dimusnahkan. Sedangkan arsip yang bernilai guna berlanjut harus diserahkan kepada lembaga kearsipan perguruan tinggi.

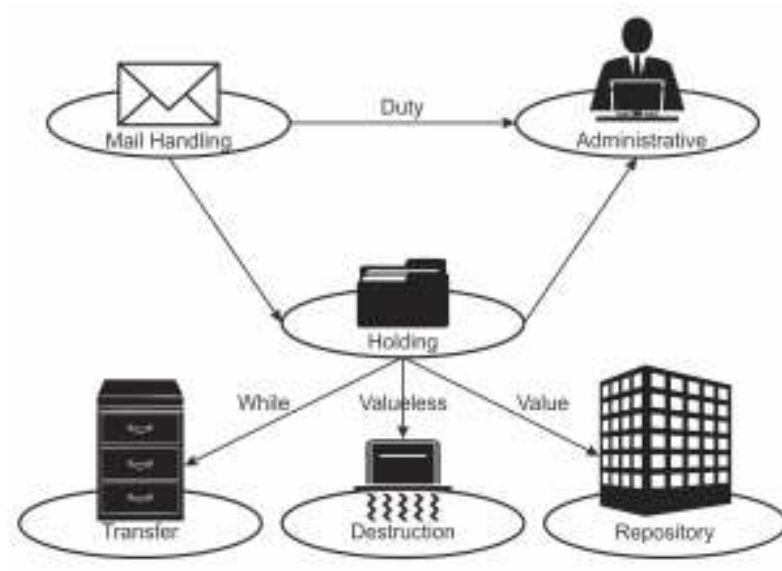

Gambar 1. Kerangka Pemikiran Sumber: Analisis Peneliti

Menurut Setyawan (2018:38), dalam penyelenggaraan kearsipan, tata persuratan (mail handling) merupakan bagian dalam penyelenggaraan kearsipan. Dalam kajian kearsipan, pengurusan surat masuk termasuk dalam bagian penciptaan (creation) arsip. Sementara itu, penciptaan arsip merupakan bagian dari pengelolaan arsip dinamis (records management). Menurut Yusof dan Chell (2000:138), konsep records management digambarkan sebagai life cycle of paper records (daur hidup arsip berbasis kertas). Arsip aktif disimpan selama jangka waktu tertentu, lalu memasuki tahap semi-aktif, dan kemudian memasuki masa non-aktif. Arsip non-aktif akan dimusnahkan atau berubah menjadi arsip statis (archive). Gambaran pengelolaan arsip berabasis kertas menurut Yusof dan Chell adalah sebagai berikut: 


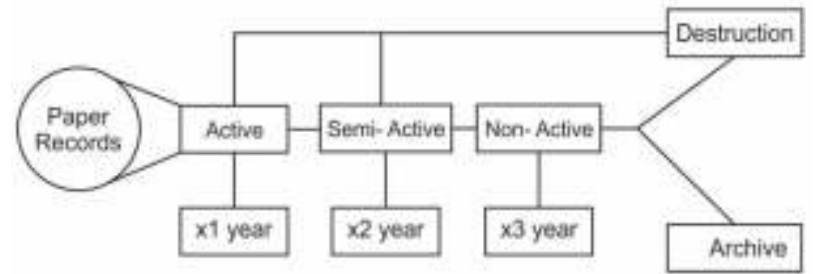

Gambar 2. Life Cycle of Paper Records Sumber: Zawiyah M. Yusof and Robert W. Chell, 2000, Information Development, 16 (3), 135-141

Sementara itu, menurut Pearce-Moses (2005:334), records management adalah pengendalian arsip secara sistematis dan administratif sepanjang siklus hidup mereka untuk memastikan efisiensi dan penghematan dalam penciptaan, penggunaan, penanganan, pengendalian, pemeliharaan, dan disposisi. Deserno dan Kynaston (2005:1) berpendapat bahwa program records management sangat diperlukan untuk program arsip. Program records management berkontribusi pada program arsip statis yang efektif dengan membedakan nilai arsip sebagaimana diidentifikasi dalam jadwal retensi arsip dinamis, yang menentukan periode retensi yang diperlukan dan disposisi akhir berdasarkan nilai tersebut. Arsip statis mendokumentasikan transaksi, kebijakan, keputusan, atau layanan yang signifikan dan memiliki nilai historis, hukum, atau administratif yang bersifat permanen.

Berbagai konsep records management ini sesuai dengan konsep life cycle of records yang dicetuskan Theodore Rosevelt Schellenberg yang membagi daur hidup arsip dinamis menjadi tiga, yaitu: tahap lahir arsip dinamis (penciptaan dan penerimaan), tahap hidup produktif arsip dinamis (penggunaan dan pemeliharaan), dan tahap kematian arsip dinamis (tahap penyusutan) atau pindah ke tempat arsip statis (reinkarnasi)
(Ricks and Gow: 1998:4).

Dalam kajian kearsipan di Indonesia, records management sering dimaknai dengan istilah pengelolaan arsip dinamis. Dalam Undang-undang nomor 43 tahun 2009 tentang kearsipan disebutkan bahwa pengelolaan arsip dinamis adalah adalah proses pengendalian arsip dinamis secara efisien, efektif, dan sistematis meliputi penciptaan, penggunaan dan pemeliharaan, serta penyusutan arsip. Dalam tahapan pengelolaan arsip dinamis, pembuatan dan penerimaan surat merupakan kegiatan penciptaan arsip.

Bertambahnya volume arsip dinamis hasil dari penciptaan harus dikendalikan dengan cara pengurangan. Kegiatan pengurangan arsip dinamis disebut sebagai penyusutan arsip dinamis. Penyusutan arsip dinamis adalah kegiatan pengurangan jumlah arsip dengan cara pemindahan arsip inaktif dari unit pengolah ke unit kearsipan, pemusnahan arsip yang tidak memiliki nilai guna, dan penyerahan arsip statis kepada lembaga kearsipan (UU no 43 tahun 2009). Sementara itu, penyusutan arsip dinamis menurut Pearce-Moses (2005), adalah pemindahan arsip, terutama arsip inaktif, ke tempat akhir mereka, baik berupa pemusnahan maupun transfer sebagai arsip statis. Sebagai catatan, penyusutan tidak identik dengan pemusnahan. Cara dan waktu penyusutan biasanya dijelaskan pada jadwal retensi. Menurut The National Archives (2011:4), penyusutan arsip dinamis dimungkinkan dilakukan dengan cara: penghancuran, transfer arsip ke layanan eksternal, penilaian kembali (jika diperlukan), dan transfer arsip ke pihak berikutnya (jika ada). 
Pemindahan arsip inaktif dilakukan terhadap arsip inaktif dari unit pengolah ke unit kearsipan. Arsip inaktif merupakan bagian dari arsip dinamis (arsip yang digunakan secara langsung dalam kegiatan pencipta arsip dan disimpan selama jangka waktu tertentu), yang frekuensi penggunaannya telah menurun. Prosedur pemindahan meliputi kegiatan penyeleksian oleh tim, pembuatan daftar arsip inaktif yang akan dipindahkan, dan penataan arsip inaktif. Pada tahun 2018, arsip inaktif yang dipindah adalah arsip dinamis yang tercipta pada tahun 2015 dan telah memasuki masa inaktif berdasarkan Jadwal Retensi Arsip Dinamis (JRAD).

Deserno dan Kynaston (2005:1) menyatakan bahwa arsip dinamis yang tidak memiliki nilai guna, hanya perlu disimpan sementara. Pemusnahan secara teratur dan konsisten akan memiliki dampak positif berupa penghematan waktu, ruang, dan biaya secara signifikan. Menurut Peraturan Pemerintah Nomor 28 tahun 2012 tentang Pelaksanaan UU nomor 43 tahun 2009 tentang kearsipan, pemusnahan dilakukan terhadap arsip dinamis yang: 1) tidak memiliki nilai guna; 2) telah habis retensinya dan berketerangan dimusnahkan berdasarkan JRAD; 3) tidak ada peraturan perundang-undangan yang melarang; dan 4) tidak berkaitan dengan penyelesaian proses suatu perkara. Prosedur pemusnahan arsip dinamis dilakukan melalui tahapan: a) pembentukan panitia penilai arsip dinamis; b) penyeleksian arsip dinamis berdasarkan ketentuan; c) pembuatan daftar arsip usul musnah oleh arsiparis di unit kearsipan; d) penilaian oleh panitia penilai arsip dinamis; e) permintaan persetujuan dari pimpinan pencipta arsip dinamis; f) penetapan arsip dinamis yang akan dimusnahkan; dan g) pelaksanaaan pemusnahan. Proses pelaksanaaan pemusnahan dilakukan dengan ketentuan sebagai berikut:

1. dilakukan secara total sehingga fisik dan informasi arsip dinamis musnah dan tidak dapat dikenali;

2. disaksikan oleh sekurang-kurangnya 2 (dua) pejabat dari unit hukum dan/atau pengawasan dari lingkungan pencipta arsip dinamis yang bersangkutan; dan disertai penandatanganan berita acara yang memuat daftar arsip dinamis yang dimusnahkan.

Penyerahan arsip statis dilakukan oleh pencipta arsip kepada lembaga kearsipan. Dalam ranah perguruan tinggi, lembaga kearsipan adalah lembaga kearsipan perguruan tinggi, atau disebut juga arsip perguruan tinggi, yaitu lembaga kearsipan berbentuk satuan organisasi perguruan tinggi, baik negeri maupun swasta yang melaksanakan fungsi dan tugas penyelenggaraan kearsipan di lingkungan perguruan tinggi. Sementara itu, arsip statis adalah arsip yang dihasilkan oleh pencipta arsip karena memiliki nilai guna kesejarahan, telah habis retensinya, dan berketerangan dipermanenkan yang telah diverifikasi baik secara langsung maupun tidak langsung oleh Arsip Nasional Republik Indonesia dan/atau lembaga kearsipan (UU nomor 43 tahun 2009). Prosedur penyerahan arsip statis dilaksanakan sebagai berikut: a) penyeleksian dan pembuatan daftar arsip usul serah oleh arsiparis di unit kearsipan; b) penilaian oleh panitia penilai arsip terhadap arsip usul serah; c) pemberitahuan akan menyerahkan arsip statis oleh pimpinan pencipta 
arsip kepada kepala lembaga kearsipan sesuai wilayah kewenangannya disertai dengan pernyataan dari pimpinan pencipta arsip bahwa arsip yang diserahkan autentik, terpercaya, utuh, dan dapat digunakan; d) verifikasi dan persetujuan dari kepala lembaga kearsipan sesuai wilayah kewenangannya; e) penetapan arsip yang akan diserahkan oleh pimpinan pencipta arsip; dan f) pelaksanaaan serah terima arsip statis oleh pimpinan pencipta arsip kepada kepala lembaga kearsipan dengan disertai berita acara dan daftar arsip yang akan diserahkan. Dalam penyelenggaraan kearsipan, dikenal istilah pengelolaan arsip statis, yaitu proses pengendalian arsip statis secara efisien, efektif, dan sistematis meliputi akuisisi, pengolahan, preservasi, pemanfaatan, pendayagunaan, dan pelayanan publik dalam suatu sistem kearsipan nasional.

Idealnya setiap perguruan tinggi negeri memiliki lembaga kearsipan perguruan tinggi/Arsip Universitas. Hal ini sesuai amanat Undang-undang nomor 43 tahum 2009 tentang Kearsipan. Maher (1992;17) menyatakan bahwa Arsip Univeritas/university archives adalah suatu program terpadu yang terdiri dari kebijakan, sumber daya manusia, dan sumber daya lainnya berupa klhazanah yang dimilikinya, serta fasilitas yang tersedia untuk merawat dan melestarikan serta menyediakan akses warisan dokumenter suatu perguruan tinggi.

Lembaga kearsipan perguruan tinggi atau Arsip Universitas seharusnya memiliki kedudukan yang jelas untuk menghindari kerancuan unit penyedia informasi di universitas. Arsip perguruan tinggi seharusnya menjadi lembaga terpisah dari unit kerja pencipta arsip agar tugas dan fungsinya jelas dan tidak tumpeng tindih. Brown \& Yakel (1996:286) berpendapat bahwa hampir setiap unit di kampus bergantung pada informasi dalam berbagai bentuk dalam pelaksanaan kegiatan sehari-hari. Lingkungan informasi menjadi bergejolak di kampus dengan meningkatnya persaingan dan layanan yang tumpang tindih antar penyedia informasi.

\section{PEMBAHASAN}

\section{Kedudukan dan Fungsi Sub-Bagian Tata Usaha dan Kearsipan UNY}

Sub-Bagian Tata Usaha dan Kearsipan UNY merupakan sub bagian di bawah Bagian Umum, Hukum, Tatalaksana, dan Perlengkapan (UHTP) Biro Umum, Perencanaan, dan Keuangan (BUPK). Menurut Peraturan Menteri Pendidikan Nasional Republik Indonesia Nomor 23 Tahun 2011 tentang Organisasi dan Tata Kerja Universitas Negeri Yogyakarta, Sub-Bagian Tata Usaha dan Kearsipan mempunyai tugas melakukan urusan persuratan, kearsipan, keprotokolan, dan dokumentasi.

Salah satu tugas Sub-Bagian Tata Usaha dan Kearsipan UNY adalah melakukan urusan persuratan. Surat masuk dan surat keluar bagi dan dari pimpinan serta staf di lingkungan rektorat UNY menjadi tugas Sub-Bagian tersebut.

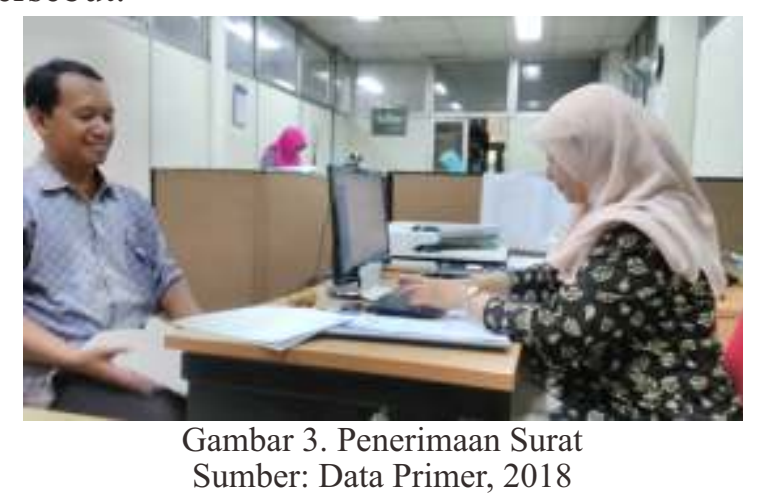




\section{Tata Persuratan di Rektorat UNY}

Sesuai hasil wawancara dengan Kepala Sub-Bagian Tata Usaha dan Kearsipan UNY pada 15 November 2018, diketahui bahwa surat masuk ke UNY diterima melalui satu pintu yaitu Sub-Bagian Tata Usaha dan Kearsipan, kemudian disampaikan kepada pimpinan universitas. Dalam penyampaian dan disposisi surat, UNY menggunakan aplikasi persuratan My Office, yaitu dengan cara memindai surat masuk kemudian dilakukan input data ke dalam database aplikasi. Sementara itu, surat asli akan disimpan di central file.

Berikut beberapa wawancara mengenai pengurusan surat masuk dan surat keluar melalui Sub-Bagian TU dan Kearsipan:

"Surat masuk ke rektorat semuanya diterima di Sub-Bag TU dan Kearsipan, lalu kami sampaikan kepada pimpinan melalui aplikasi My Office dan kami arsipkan suratnya. Surat masuk lewat TUK terus discan, lalu masuk aplikasi. Kalau surat keluar, jadi unit kerja itu bikin surat, nanti kami mintakan tanda tangan pimpinan, terus distempel dan diberi nomor. Suratnya rangkapdua, satu diarsip, satunya dikirim" (wawancara dengan Nurwahyu Kurniasari, 14 November 2018).

"jadi My Office itu sebuah aplikasi untuk menyampaikan surat secara elektronik. Jadi disposisinya juga secara elektronik, tidak melibatkan surat secara fisik." (wawancara dengan Rakhmat Rajendra, 14 November 2018).

Berikut adalah alur surat masuk di Rektorat UNY melalui Sub-Bagian Tata Usaha dan Kearsipan:

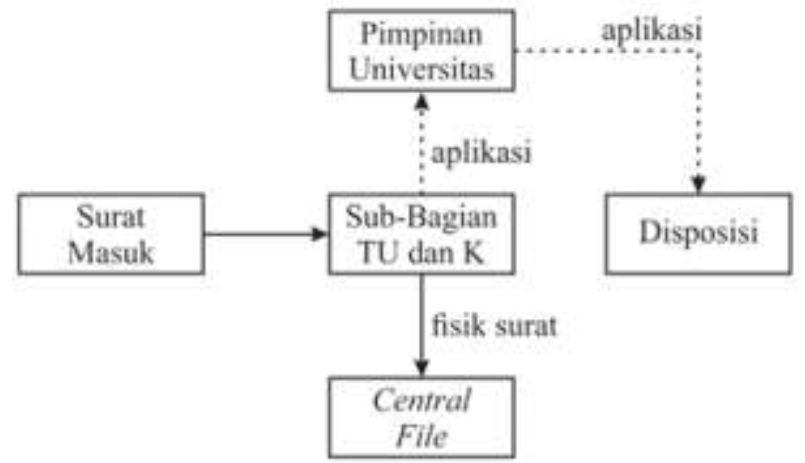

Gambar 4. Alur Surat Masuk Sumber: Data Primer, 2018

Sementara itu, surat keluar dari rektorat UNY juga melalui satu pintu, yaitu Sub-Bagian Tata Usaha dan Kearsipan. Surat dibuat oleh unit kerja di lingkungan rektorat rangkap dua, lalu akan dimintakan tanda tangan pimpinan universitas melalui Sub-Bagian TU dan Kearsipan. Surat tersebut kemudian disahkan dan diberi nomor surat, kemudian surat dikirim ke tujuan. Sementara itu, salinan surat disimpan di central file. Berikut adalah alur surat keluar di Rektorat UNY:

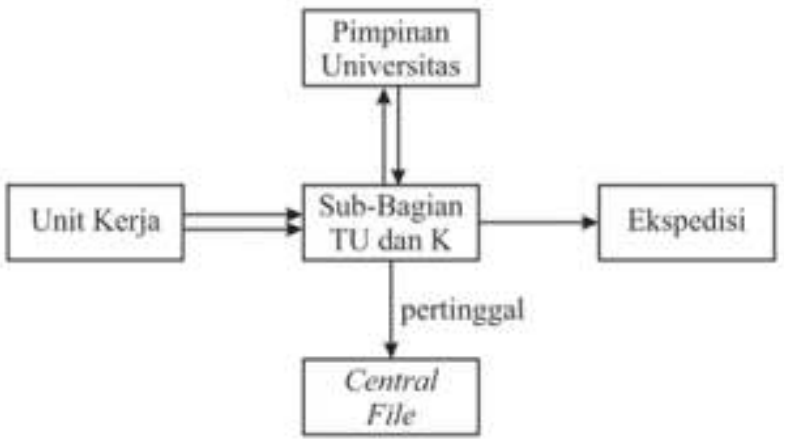

Gambar 5. Alur Surat Keluar Sumber: Data Primer, 2018 


\section{Kegiatan Pemberkasan Arsip Aktif}

Selain mengurus surat masuk dan keluar, Sub-Bagian Tata Usaha dan Kearsipan juga melaksanakan pengarsipan. Arsip dinamis tercipta melalui kegiatan pengurusan surat masuk dan surat keluar. Arsip dinamis yang tercipta kemudian diberkaskan sesuai dengan klasifikasi arsip dinamis. Arsip aktif diberkaskan menggunakan sarana hanging map/map gantung, kemudian disimpan dalam filing cabinet. Sebagai alat temu kembali arsip aktif, UNY membuat daftar arsip aktif setiap akhir tahun. Untuk pencarian arsip aktif sebelum disusunnya daftar arsip aktif, digunakan aplikasi persuratan elektronik My Office yang dapat menunjukkan lokasi simpan arsip aktif yang tercipta.

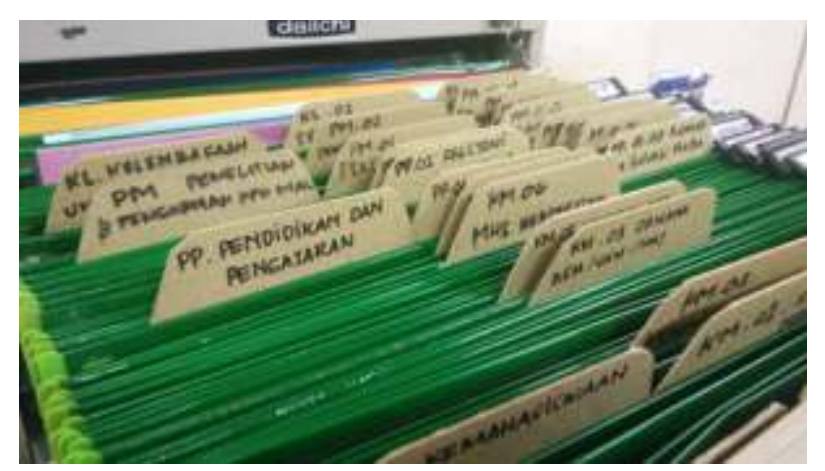

Gambar 6. Pemberkasan Arsip Aktif Sumber: Data Primer, 2018

\section{Kegiatan Penyusutan Arsip}

Setelah diberkaskan, tahap selanjutnya setelah arsip dinamis tercipta adalah penggunaan dan pemeliharaan, serta tahap akhirnya adalah penyusutan arsip dinamis. Penyusutan arsip dinamis di UNY dilakukan berdasarkan Peraturan Rektor No. 7 Tahun 2017 tentang Jadwal Retensi Arsip di Lingkungan Universitas Negeri Yogyakarta.

Ribuan arsip dinamis tercipta dari kegiatan surat menyurat setiap tahunnya. Pada tahun 2015, tercatat 9985 surat masuk melalui Subbagian TU dan Kearsipan UNY. Sementara itu, pada tahun 2016 tercatat surat masuk sebanyak 9573, dan selama tahun 2017 tercatat 9987 surat masuk.

Sementara itu, surat keluar tercatat sebanyak 3578 pada tahun 2015, 3693 pada tahun 2016, dan 5176 pada tahun 2017. Dari kegiatan surat menyurat, jumlah arsip yang tercipta dari surat masuk dan surat keluar pada tahun 2015 adalah 13563 surat, tahun 2016 sebanyak 13266 surat, dan tahun 2017 sebanyak 15163 surat. Berikut tabel penciptaan surat tahun 2015-2017:

\begin{tabular}{|c|c|c|c|}
\hline Tahun & Surat Masuk & Surat Keluar & Jumlah \\
\hline 2015 & 9985 & 3578 & 13563 \\
\hline 2016 & 9573 & 3693 & 13266 \\
\hline 2017 & 9987 & 5176 & 15163 \\
\hline
\end{tabular}

Tabel 1. Jumlah Surat Masuk dan Surat Keluar tahun 2015-2017

Sumber: Data Primer, 2018

Sub-Bagian Tata Usaha dan Kearsipan UNY telah melaksanakan penyusutan arsip yang tidak bernilai guna dalam rangka pengurangan jumlah arsip dinamis. Sejak tahun 2015, penyusutan arsip yang dilakukan adalah:

1. Pemindahan arsip inaktif

Dari hasil observasi, diketahui bahwa arsip inaktif yang telah dipindahkan adalah arsip inaktif yang tercipta pada tahun 20152016. Pemindahan arsip inaktif dilakukan pada arsip inaktif yang sudah mempunyai daftar. Jumlah arsip ianktif yang telah dipindahkan yaitu tahun 2015 sebanyak 121 berkas, dan tahun 2016 sebanyak 154 berkas, yaitu terdiri dari : 
a. Surat Tugas Kedinasan

b. Kegiatan Peringatan Upacara Hari Besar Nasional

c. Kegiatan Peringatan Upacara Dies Natalis

d. Kegiatan Peringatan Hari Besar Keagamaan

e. Kerjasama penerimaan siswa Prakerin

f. Undangan rapat koordinasi \& notulen

g. Undangan dari Perguruan Tinggi lain

h. Ucapan belasungkawa \& pelepasan jenazah Pimpinan

i. Kerjasama dengan Bank

j. Kerjasama dengan Pemerintah Pusat

k. Penawaran ucapan selamat \& sukses

1. Penawaran Beasiswa

m. Surat Edaran

n. Ijin Penelitian

o. Permohonan narasumber

p. Kerjasama dengan Perguruan Tinggi

q. Kerjasama dengan swasta

r. Kerjasama dengan Pemerintah Daerah

s. Permohonan kunjungan

t. Acara Kedinasan Pimpinan

u. Acara Senam Rutin Ikapen

v. Permohonan izin mengikuti seleksi beasiswa bagi Dosen \& Karyawan

w. Pelatihan Pengelolaan Arsip Dinamis

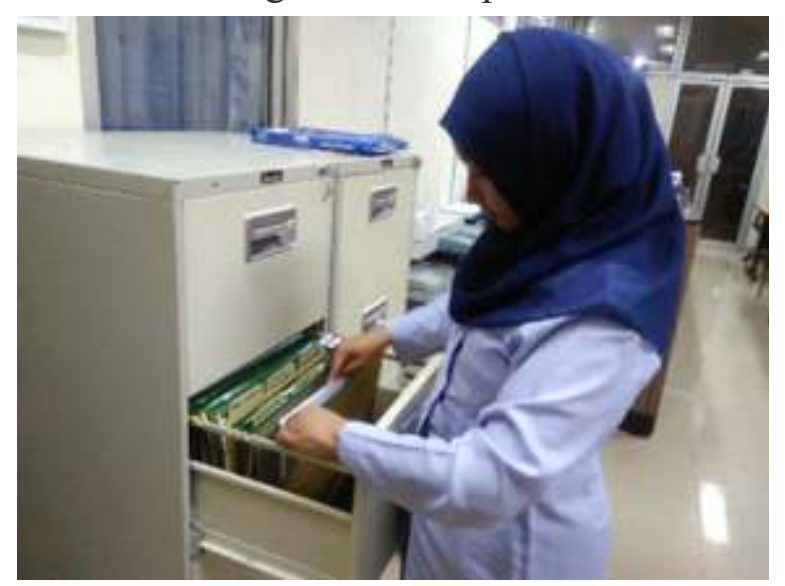

Gambar 7. Kegiatan Pemindahan Arsip Inaktif Sumber: Data Primer, 2018
Pemindahan arsip inaktif dilakukan dari central file ke records center pada tahun 2018. Hal tersebut didasarkan pada peraturan mengenai jadwal retensi arsip dinamis baru dibuat pada tahun 2017, yaitu Peraturan Rektor No. 7 Th. 2017 tentang Jadwal Retensi Arsip Dinamis.

2. Pemusnahan arsip dinamis yang tidak bernilai guna.

Pemusnahan arsip dinamis yang tidak bernilai guna yang tercipta di UNY pada tahun 2015-2017 belum pernah dilakukan. Kegiatan ini belum terlaksana karena keterbatasan jumlah sumber daya manusia kearsipan. Saat ini, Sub-Bagian Tata Usaha dan Kearsipan UNY dipimpin oleh seorang Kepala SubBagian yang membawahi tiga orang arsiparis, dua orang tenaga administrasi, dan satu orang pegawai di bidang teknologi informasi dan komunikasi. Keterbatasan yang dimaksud adalah keterbatasan waktu dalam melakukan penilaian arsip dinamis usul musnah, karena ketujuh staf yang ada lebih banyak mengalokasikan waktunya dalam pengurusan surat masuk dan surat keluar yang volumenya cukup tinggi. Dari hasil wawancara, seluruh staf sepakat bahwa sumber daya manusia kearsipan dirasa masih kurang. Berikut hasil wawancara dengan arsiparis UNY:

"kami mengalami kesulitan dalam melaksanakan pemusnahan arsip, soalnya orangnya sedikit, dan waktunya habais untuk mengurusi surat-surat." (wawancara dengan Heru Subekti, 16 November 2018).

"mengurusi surat saja sudah kehabisan waktu, apalagi melakukan penilaian, jadi kami kesulitan melakukan pemusnahan arsip." (wawancara dengan Sulustiati Aeni, 16 November 2018). 


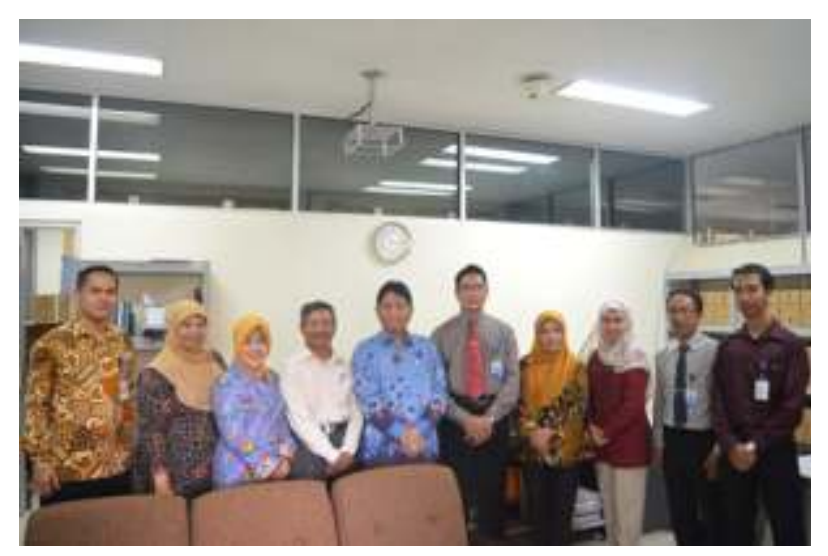

Gambar 8. Sumber Daya Manusia Kearsipan Rektorat UNY bersama Kepala ANRI, Dr. Mustari Irawan, M.P.A. Sumber: Data Primer, 2017

Dalam rangka merespon persoalan tersebut, Sub-Bagian TU dan Kearsipan mengusulkan kepada pimpinan universitas untuk menambah jumlah sumber daya manusia kearsipan. Selain itu, sumber daya manusia kearsipan ditingkatkan kompetensinya dalam bidang kearsipan melalui berbagai pendidikan dan pelatihan.

\section{Penyerahan arsip statis}

Sebagaimana kegiatan pemusnahan, UNY belum melaksanakan penyerahan terhadap arsip statis yang tercipta sejak tahun 2015 hingga tahun 2017 di Rektorat UNY. Selain karena keterbatasan sumber daya manusia, UNY belum memiliki lembaga kearsipan perguruan tinggi. Saat ini arsip statis belum dikelola karena belum adanya kejelasan mengenai pihak-pihak yang berwenang mengelola arsip statis.

Namun sementara ini Sub-Bagian Tata Usaha dan Kearsipan menerima penyerahan arsip dari Sub-Bagian Hukum dan Tata Laksana berupa arsip produk hukum, kumpulan SK dan Peraturan Rektor, serta dari Unit Layanan Pengadaan berupa arsip surat perjanjian kontrak dan arsip kartografi. Arsip statis yang diserahkan tersebut saat ini telah diolah dan disimpan pada ruang arsip universitas oleh ketiga arsiparis di UNY.

Dalam rangka mengatasi hambatan tersebut, UNY mengusulkan kepada pemerintah untuk membentuk lembaga kearsipan perguruan tinggi yang memiliki tugas yang jelas sebagai lembaga pengelola arsip statis.

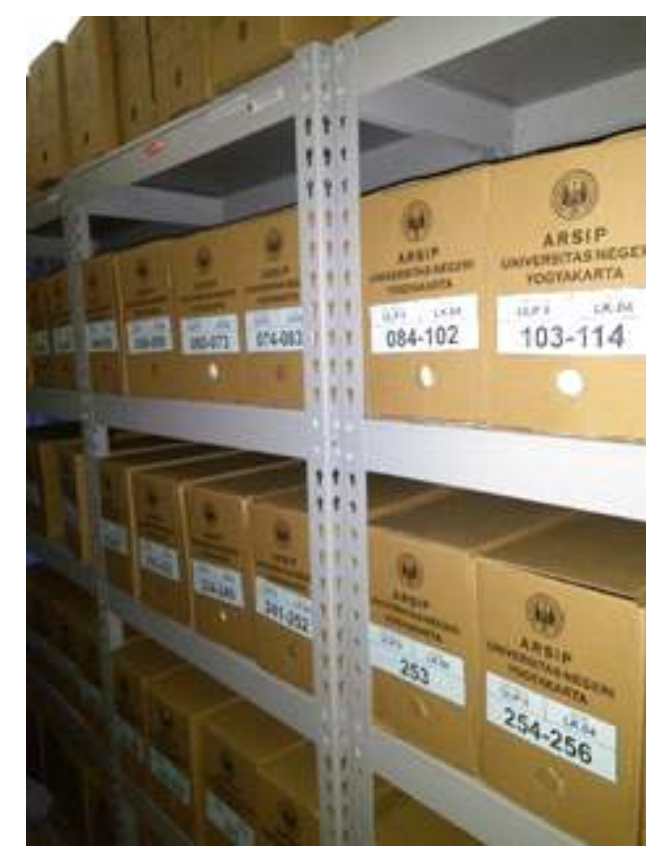

Gambar 9. Pengelolaan Arsip Statis di UNY Sumber: Data Primer, 2018

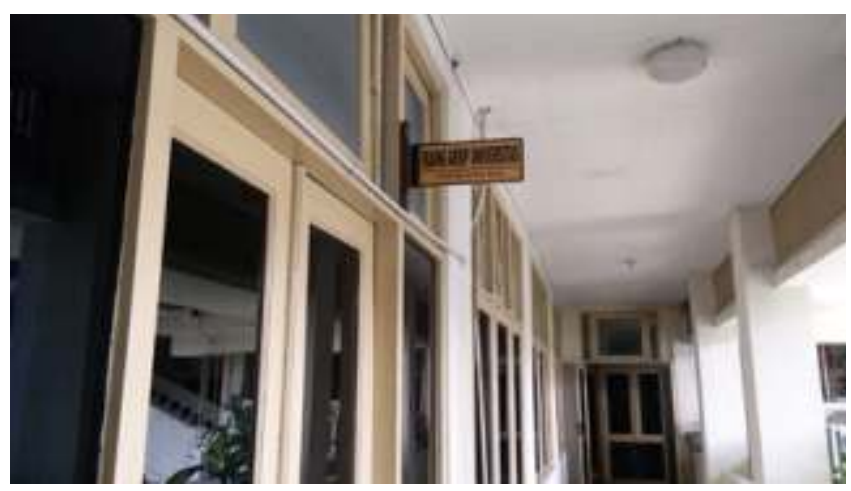

Gambar 10. Ruang Arsip Universitas Sumber: Data Primer, 2018 


\section{KESIMPULAN}

Penyelenggaraan kearsipan yang meliputi records management dan archives management masih sangat relevan diterapkan pada organisasi perguruan tinggi di Indonesia. Sejak penciptaan arsip dinamis, penggunaan dan pemeliharaan, hingga kegiatan penyusutan arsip dinamis menjadi kegiatan yang harus dilakukan dalam rangka mengelola arsip dinamis yang tercipta di universitas. Selanjutnya, arsip yang memiliki nilai berkelanjutan, atau dikenal sebagai arsip statis, harus dikelola melalui tahapan akuisisi, pengolahan, preservasi, dan akses.

Setiap perguruan tinggi seyogyanya memiliki lembaga kearsipan perguruan tinggi sebagai penyelenggara kearsipan di tingkat universitas, sehingga kegiatan penyusutan arsip dinamis berupa penyerahan arsip statis dapat terlaksana dengan baik. Saat ini UNY belum memiliki lembaga kearsipan perguruan tinggi, sehingga penyusutan arsip dinamis yang dapat dilakukan adalah sebatas pemindahan arsip inaktif dan pemusnahan arsip yang tidak benilai guna. Dalam penyelenggaraan kearsipan, perguruan tinggi sebaiknya juga didukung oleh sumber daya manusia, sarana dan prasarana, serta anggaran yang memadai. Dengan tersedianya berbagai kebutuhan tersebut, diharapkan pengelolaan arsip di perguruan tinggi menjadi optimal dan mencapai hasil yang memuaskan.

\section{Daftar Pustaka}

, Historical Development of the Records Disposal Policy of the Federal Government Prior To 1934, diakses dari http://americanarchivist.org/doi/pdf/10.17 723/Aarc.7.3.1403805446475352 pada 20 November 2018

Brown. W.E \& Yakel, Elizabeth. 1996. Redefining the Role of College and University Archives in the Information Age. American Archivists. 59. 272-287.

Deserno, Ineke. dan Kynaston, Donna., 2005, A Records Management Program that Works for Archives. Information Management Journal, 39, Iss. 3. 60-62 https://search.proquest.com/docview/22 7752987 ?accountid $=13771$

Idrus, Muhammad., 2009, Metode Penelitian Ilmu Sosial; Pendekatan Kualitatif dan Kuantitatif (Edisi Kedua). Yogyakarta: Universitas Islam Indonesia.

Maher, W.J. 1992. The Management of College and University Archives. Metuchen, N.J.: The Scarecrow Press

Nazir, Moh., 2017, Metode Penelitian, Bogor: Ghalia Indonesia

Paknad, D., dan Luellig, L., 2011, Are You Saving Money With a Defensible Records Disposal Startegy?, Pipeline \& Gas Journal, 238 (2), 60-62.

Pearce-Moses, R., 2005, A Glosary of Archival and records Therminology, Chicago: Society of American Archivists

Pendit, P.L., 2003, Penelitian Ilmu Perpustkaan dan Informasi: Suatu Pengantar Diskusi Epistemologi dan Metodologi. Jakarta: JIP-FSUI.

Peraturan Menteri Riset, Teknologi, dan Pendidikan Tinggi Republik Indonesia nomor 51 tahun 2015 tentang Tata 
Naskah Dinas di Lingkungan Kementerian Riset, Teknologi, dan Pendidikan Tinggi

Peraturan Pemerintah Nomor 28 tahun 2012 tentang Pelaksanaan UU nomor 43 tahun 2009 tentang Kearsipan

Ricks, M \& Gow, K. 1988. Information Resources Management. A Records System Approach. 2nd edition. Cincinnati: South-Western Publishing

Setyawan, Herman., 2018, Strategi Organizational Development Melalui Aplikasi Persuratan dan Kearsipan Elektronik My Office di Universitas Negeri Yogyakarta. Diplomatika, 2(1),

\section{$34-43$}

Sevilla, Consoelo dkk., 1993, Pengantar Metode Penelitian. Jakarta: Universitas Indonesia.

The National Archives, 2011, Guide 8 Disposal o f $\mathrm{R}$ e c o r d s , www.justice.gov.uk/guidance/docs/foisection-46-code-of-practice.pdf

Undang-undang nomor 43 tahun 2009 tentang Kearsipan.

Yusof, Zawiyah M. , dan Chell, Robert W., 2000. The Records Life Cycle: an inadequate concept for technology-generated records. Information Development, 16 (3), 135-141 